\title{
INOVASI RENGGINANG SEBAGAI PANGAN SUMBER SERAT DENGAN PENAMBAHAN RUMPUT LAUT Undaria pinnatifida
}

\section{[Inovation of Rengginang as Food Source of Fiber with The Addition of Undaria pinnatifida Seaweed]}

\author{
Istiqomaturrosyidah ${ }^{\mathbf{1}^{*}}$, Erni Sofia Murtini ${ }^{\mathbf{1}}$ \\ 1) Jurusan Teknologi Hasil Pertanian, FTP, Universitas Brawijaya \\ Jl. Veteran, Malang 65145 \\ *Email: istiq0308@gmail.com \\ Diterima 19 Januari 2021 / Disetujui 5 Maret 2021
}

\begin{abstract}
Rengginang is a traditional Indonesian food that made from steamed glutinous rice, formed into round plates, dried and then fried. Composite ingredient prepared from seaweed were used for making rengginang with higher fiber content. The purpose of this study was to determine the effect of the subtitution of seaweed on the physical, chemical, and organoleptic quality of rengginang along to determine the concentration of seaweed which can make rengginang as a source of fiber. This research was conducted by using Randomized Block Design (RAK) with single factor that is subtitution of seaweeds with concentration $0,5,10,15,20$, and 25\%. The best treatment of rengginang was obtained from the subtitution of $15 \%$ seaweed with water content $10.94 \%$ (bk), evaporation of water $4.38 \%$, and swelling volume $112.73 \%$, and hedonic value which includes color 5.50 (kinda like); aroma 6,10(like); taste 6.00 (like); and texture 5,7 (kinda like)
\end{abstract}

Keywords: Rengginang, Seaweed, Source of Fiber

\section{ABSTRAK}

Rengginang merupakan makanan tradisional Indonesia yang terbuat dari beras ketan yang dikukus, dibentuk lempengan bulat, dikeringkan kemudian digoreng. Penambahan bahan dari rumput laut digunaka untuk membuat rengginang memiliki kandungan serat yang tinggi. Tujuan dari penelitian ini adalah untuk mengetahui pengaruh penambahan rumput laut terhadap kualitas fisik, kimia, dan organoleptik rengginang serta untuk mengetahui konsentrasi rumput laut yang dapat membuat rengginang sebagai sumber serat. Penelitian dilakukan menggunakan Rancangan Acak Kelompok faktor tunggal yaitu penambahan rumput laut pada konsentrasi 0, 5, $10,15,20$, dan $25 \%$. Rengginang perlakuan terbaik didapatkan dari penambahan rumput laut $15 \%$ dengan kadar air 10,94\% (bk), penguapan air 4,38\%, volume pengembangan $112,73 \%$, serta nilai hedonik yang meliputi warna 5,50 (agak suka) ; aroma 6,10 (suka) ; rasa 6,00 (suka); dan tekstur 5,7 (agak suka)

Kata Kunci : Rengginang, Rumput Laut, Sumber Serat

\section{PENDAHULUAN}

Rengginang merupakan salah satu makanan tradisional yang mulai tergeser oleh makanan modern. Hal tersebut terbukti dari hasil wawancara dengan salah satu pemilik UKM rengginang di Desa Sumberpucung, Kabupaten Malang bahwa produksi rengginang cenderung menurun kecuali pada hari-hari besar seperti Idul Fitri. Berdasarkan Badan Pusat Statistika tentang rata-rata konsumsi beras per kapita seminggu yang berasal dari komoditas mengandung beras menurut daerah tempat tinggal (perdesaan dan perkotaan), konsumsi beras ketan pada tahun 2017 adalah 5,633 gram/kapita/seminggu, sedangkan pada tahun 2018 menurun menjadi 4,900 gram/kapita/seminggu (BPS, 2018). Saat ini, jenis makanan yang sedang tren adalah makanan sehat seperti rendah lemak, rendah gula, sumber serat. Berdasarkan survey yang dilakukan oleh International Food Information Council Foundation (2018), 82\% orang akan memilih makanan sehat dari kandungan seratnya, sedangkan menurut Rahma, dkk., (2017), rata-rata konsumsi serat di Indonesia hanya 10,5 gram per hari. Berdasarkan PKBPOM No 9 Tahun 2016, acuan label gizi konsumsi serat idealnya adalah 30 gram per hari (BPOM, 2016).

Berdasarkan hasil survei yang telah dilakukan pada tahun 2019, dengan menyebarkan kuisioner online pada rentang 
usia 17-24 tahun, bahwa $62,3 \%$ dari 61 tanggapan memilih rumput laut untuk ditambahkan ke dalam rengginang. Penambahan rumput laut, misalnya jenis wakame, diperkirakan dapat meningkatkan daya tarik rengginang bagi konsumen. Rumput laut wakame mengandung jenis fikokoloid berupa alginat yang dapat berfungsi untuk mengurangi hipertensi (Pereira, 2011). Rumput laut wakame merupakan salah satu rumput laut dengan kandungan serat yang tinggi. Kandungan serat totalnya mencapai 33,6\% berat kering yang terdiri dari serat tidak larut $16,3 \%$ dan serat larut 17,3\% (Dwiyitno, 2011). Selain sumber serat, rumput laut ini juga mudah diolah dikarenakan bentuknya seperti lembaran daun. Oleh karena itu, rengginang ditambahkan dengan rumput laut wakame. Selain serat dari rumput laut, juga terdapat pati resisten yang terbentuk dari proses pengolahan rengginang. Menurut Musita (2012) pati resisten merupakan pati yang tidak dapat dicerna oleh enzim-enzim pencernaan dan akan difermentasi di dalam usus besar sehingga pati resisten memilki sifat yang hampir sama dengan serat.

Beberapa penelitian terdahulu yang dilakukan oleh Ardani dan Yanuar (2018), menyatakan bahwa penambahan rumput laut jenis Eucheuma spinosum dari konsesntrasi 15$30 \%$ pada kerupuk dapat menyebabkan kadar seratnya meningkat. Penelitian lain dilakukan oleh Yilmaz and Elif (2017), menggunakan penggabungan serat dari ekstrak biji jeruk, biji anggur dan serat gandum dapat meningkatkan kadar serat pada crackers (kerupuk). Penambahan gabungan serat dari ekstrak tersebut ditambahkan hingga 2,9\%.

Tujuan dari penelitian ini adalah untuk mengetahui apakah penambahan rumput laut dapat mempengaruhi kualitas fisik, kimia, dan organoleptik rengginang serta untuk mendapatkan konsentrasi rumput laut yang dapat membuat rengginang sebagai sumber serat dengan karakteristik yang dapat diterima.

\section{BAHAN DAN METODE}

\section{Bahan}

Bahan yang digunakan dalam pembuatan rengginang adalah beras ketan putih (food station, rumput laut wakame, air, minyak goreng, bawang putih, dan garam. sedangkan bahan yang digunakan dalam analisa adalah $\mathrm{K}_{2} \mathrm{SO}_{4}, \mathrm{CuSO}_{4}$, pelarut $\mathrm{PE}$, etanol, $\mathrm{H}_{3} \mathrm{BO}_{3}, \mathrm{HNO}_{3}, \mathrm{NaOH}$ (Merck), $\mathrm{HCl}, \mathrm{NaCl}$, $\mathrm{H}_{2} \mathrm{SO}_{4}$ (Merck), akuades, indikator kjeldahl, dan kertas saring.

\section{Alat}

Alat yang digunakan dalam pembuatan rengginang adalah blender, panci pengukus, pisau, sendok, loyang, kompor, panci perebus, pencetak rengginang, dan baskom. Sedangkan alat yang digunakan untuk analisa adalah oven listrik (memmert), desikator (simax), soxhelt extractor, kjeldahl desilator unit (Buchi), lemari asam, Spektrofotometer, texture analyzer (Imada ZP-200 N), kompor listrik, sentrifuge, tanur listrik (thermolyne), waterbath (Memmert), alumunium foil, kapas, dan glassware yang mendukung.

\section{Desain Penelitian}

Rancangan peneilitian yang digunakan adalah Rancangan Acak Kelompok (RAK) dengan faktor tunggal yaitu penambahan rumput laut pada konsentrasi $0,5,10,15,20$, dan 25\%. Sehingga didapatkan 6 perlakuan. Setiap perlakuan akan dilakukan ulangan sebanyak 5 kali sehingga didapatkan 30 satuan percobaan. Dikarenakan adanya pandemi COVID 19, penelitian hanya terlaksana sebanyak 3 kali ulangan, sehingga hanya didapatkan 18 satuan percobaan.

\section{Tahapan Penelitian}

Penelitian ini dilakukan dalam 2 tahapan, yiatu preparasi rumput laut dan pembuatan rengginang. Preparasi rumput laut dilakukan dengan rumput laut kering dihaluskan. Kemudaian diayak dengan ayakan 40 mesh. Setelah itu ditimbang sesuai konsentrasi penambahan rumput laut. 
Selanjutnya pembuatan rengginang (Modifikasi Wahyono dan Marzuki, 2003), yaitu beras ketan direndam 12 jam, kemudain ditiriskan. setelah itu, dikukus selama 5 menit dengan suhu $100^{\circ} \mathrm{C}$. Kemudian rumput laut yang telah ditimbang sesuai konsentrasi, bawang dan garam (serta $60 \mathrm{ml}$ air untuk melarutkan) dicampur hingga homogen secara manual. Kemudian dikukus kembali selama 20 meniit pada suhu $100^{\circ} \mathrm{C}$ hingga matang. Kemudian ditiriskan dan dicetak dengan diamater $2 \pm 0,2 \mathrm{~cm}$ dan tebal $1 \mathrm{~cm}$. Setelah itu, dikeringan dengan cabinet dryer suhu $60^{\circ} \mathrm{C}$ selama 12 jam. Setelah itu didapatkan rengginang matang. Keudian rengginang digoreng selama 30 detik pada suhu $170^{\circ} \mathrm{C}$.

\section{Prosedur Analisis}

Analisis dilakukan pada bahan baku yaitu rumput laut dan beras ketan (kadar air metode oven (AOAC, 2005) dan kadar serat kasar (AOAC, 1990)). Pada rengginang analisa terbagi menjadi analisa fisik (volume pengembangan (Modifikasi Sudarmadji, dkk., 1997)) analisa kimia (kadar air metode oven (AOAC, 2005), kadar serat kasar (AOAC, 1990), dan penguapan air), dan analisa organoleptik (warna, aroma, rasa, dan tekstur) (SNI 014307-1996). Kemudian dilakukan analisa pada rengginang perlakuan terbaik (kadar air metode oven (AOAC, 2005), kadar serat kasar (AOAC, 1990), dan penguapan air, volume pengembangan (Modifikasi Sudarmadji, dkk., 1997), dan analisa organoleptik (warna, aroma, rasa, dan tekstur) (SNI 01-4307-1996)). Data yang diperoleh dianalisa menggunakan ANOVA dengan selang kepercayaan $95 \%$ dan di uji lanjut menggunakan beda nyata terkecil atau (BNT) dengan a 5\%. Sedangkan untuk analisa organoleptik menggunakan metode hedonik yang diolah menggunakan metode Friedman Test. Selanjutnya untuk memilih perlakuan terbaik dari rengginang rumput laut menggunakan metode Multiple Atribute.

\section{HASIL DAN PEMBAHASAN}

\section{Kadar Serat Kasar}

Kadar serat kasar rengginang yang dibuat dari konsentrasi rumput laut 0-25\% memiliki rerata antara 1,32-7,46\% (Tabel 1). Secara statistik, diperoleh $p$ value sebesar 0,000 . Hasil $p$ value tersebut berarti adanya pengaruh yang nyata pada penambahan rumput laut berbeda terhadap kadar serat rengginang. Hasil uji lanjut BNT dengan a $5 \%$ dapat dilihat pada Tabel 1.

Tabel 1. Rerata Serat Kasar Rengginang Pada Konsentrasi Rumput Laut 0-25\%

\begin{tabular}{cc}
\hline $\begin{array}{c}\text { Konsentrasi } \\
\text { Rumput Laut } \\
(\%)\end{array}$ & BNT \\
\hline 0 & $1,32 \pm 0,01^{\mathrm{f}}$ \\
5 & $2,00 \pm 0,00^{\mathrm{e}}$ \\
10 & $3,74 \pm 0,00^{\mathrm{d}}$ \\
15 & $4,91 \pm 0,00^{\mathrm{c}}$ \\
20 & $5,99 \pm 0,00^{\mathrm{b}}$ \\
25 & $7,46 \pm 0,01^{\mathrm{a}}$ \\
\hline
\end{tabular}

Keterangan: 1. Setiap data merupakan hasil rata-rata dari tiga kali ulangan dengan \pm adalah standar eror

2. Huruf yang berbeda pada nilai kadar serat menujukkan perbedaan hasil yang signifikan

Tabel 1. menunjukkan bahwa semakin banyak rumput laut yang ditambahkan pada rengginang, maka kadar seratnya semakin tinggi. Pernyataan tersebut didukung oleh Ardani dan Yanuar (2018) dalam penelitiannya menambahkan rumput laut jenis Eucheuma spinosum sebesar $15 \%$, 20\%, 25\%, dan 30\% pada kerupuk berturut-turut mengahsilkan kadar serat sebesar 2,55\%, 2,63\%, 2,77\%, dan 2,93\%. Berdasarkan penelitian tersebut diketahui bahwa rumput laut dapat menyebabkan kadar serat kerupuk meningkat. Oleh karena itu, bahan yang mengandung serat yang tinggi apabila ditambahkan akan membuat rengginang maupun kerupuk memilki kadar serat yang tinggi pula. Hal tersebut juga didukung oleh penelitian Yilmaz and Elif (2017) bahwa kerupuk yang ditambahkan bekatul 
yang tinggi serat dapat membuat kerupuk memilki kadar serat yang juga tinggi. Proses pengolahan rengginang pada penelitian ini tidak dapat mengubah komponen serat kasar. Menurut Diana (2016) yang menyatakan pada penelitiannya bahwa kadar serat kasar tidak dapat terpengaruh oleh proses perendaman dan perebusan. Selain itu, serat kasar juga tidak dapat larut pada air dingin maupaun air panas, dan juga sulit untuk dicerna pada pencernaan manusia (Nilasari, dkk., 2017).

\section{Kadar Air}

Kadar air rengginang yang dibuat dari konsentrasi rumput laut $0-25 \%$ memiliki rerata antara 9,57-13,21\% (bk) (Tabel 2). Secara statistik, diperoleh $p$-value sebesar 0,001 . Hal tersebut menandakan adanya pengaruh yang nyata dari penambahan rumput laut berbeda terhadap kadar air rengginang. Hasil uji lanjut BNT dengan a 5\%, dapat dilihat pada Tabel 2.

Tabel 2. Rerata Kadar Air (bk) Rengginang Pada Konsentrasi Rumput Laut 0-25\%

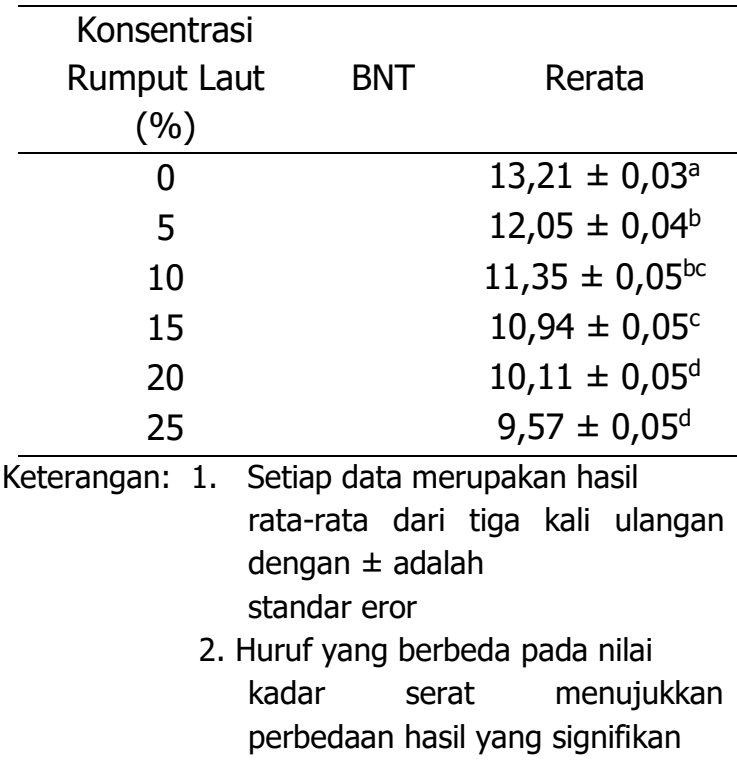

Tabel 2. menunjukkan bahwa semakin banyak rumput laut yang ditambahkan, kadar air pada rengginang semakin rendah. Hal tersebut diduga akibat adanya interaksi antar komponen pada rengginang. Komponenkomponen tersebut adalah pati, serat, dan air. Salah satu komponen terbesar pada rumput laut adalah seratnya. Serat memiliki karakteristik yang dapat mengikat air. Air yang kurang cukup untuk gelatinisasi menyebabkan gelatinisasi menjadi tidak sempurna dan akan mempengaruhi kualitas rengginang (Maureen, dkk., 2016). Selain itu, kadar air rengginang yang semakin rendah juga disebabkan karena berkurangnya proporsi beras ketannya. Amilosa dalam beras ketan merupakan pati yang mudah menyerap air dan juga mudah melepaskan air (Karjo, dkk., 2015). Apabila pati semakin sedikit, maka sedikit juga air yang terserap pati, karena lebih banyak air yang diikat oleh serat.

\section{Penguapan Air}

Penguapan air merupakan air yang teruapkan pada saat penggorengan rengginang. penguapan air didapatkan dari selisih kadar air rengginang matang dan kadar air rengginang mentah. Penguapan air rengginang yang ditambahkan dengan rumput laut $0-25 \%$ memilki rerata antara 3,79-5,20\% (Tabel 3). Secara statistik, diperoleh $p$ value sebesar 0,000 yang menandakan adanya pengaruh yang nyata dari penambahan rumput laut terhadap penguapan air pada rengginang. Berikut ini adalah hasil uji BNT penguapan air pada rengginang dengan a $5 \%$ dapat dilihat pada Tabel 3.

Tabel 3. Rerata Penguapan Air Rengginang Pada Konsentrasi Rumput Laut $0-25 \%$

\begin{tabular}{|c|c|c|}
\hline $\begin{array}{c}\text { Konsentrasi } \\
\text { Rumput Laut(\%) }\end{array}$ & BNT & Rerata \\
\hline 0 & & $5,20 \pm 0,00^{a}$ \\
\hline 5 & & $4,71 \pm 0,00^{b}$ \\
\hline 10 & & $4,48 \pm 0,00^{b}$ \\
\hline 15 & & $4,38 \pm 0,00^{b}$ \\
\hline 20 & & $3,96 \pm 0,01^{c}$ \\
\hline 25 & & $3,79 \pm 0,00^{c}$ \\
\hline
\end{tabular}

Keterangan: 1. Setiap data merupakan hasil rata-rata dari tiga kali ulangan dengan \pm adalah standar eror

2. Huruf yang berbeda pada nilai kadar serat menujukkan perbedaan hasil yang signifikan 
Tabel 3. menunjukkan bahwa semakin tinggi konsentrasi rumput laut, maka penguapan airnya semakin rendah. Salah satu komponen pada rumput laut yang dapat mempengaruhi penguapan air adalah serat. Menurut Mauren, dkk., (2016) menyatakan dalam penelitiannya bahwa serat dapat mengikat air dan mempertahankannya, sehingga tidak mudah menguap. Hal tersebut menyebabkan semakin banyak serat yang terkandung, maka semakin banyak air yang terikat, dan sedikit air juga yang menguap pada saat penggorengan rengginang. Banyaknya air yang teruapkan pada saat penggorengan, juga mempengaruhi kualitas rengginang matang.

\section{Volume Pengembangan}

Volume pengembangan rengginang yang ditambahkan rumput laut $0-25 \%$ memiliki rerata antara 70,47-198,33\% (Tabel 4). Secara statistik, diperoleh $p$ value sebesar 0,000 yang menandakan adanya pengaruh yang nyata dari penambahan rumput laut terhadap volume pengembangan pada rengginang. Berikut ini adalah hasil uji BNT volume pengembangan pada rengginang dengan a $5 \%$ dapat dilihat pada Tabel 4.

Tabel 4. Rerata Volume Pengembangan Rengginang Pada Konsentrasi Rumput Laut 0-25\%

\begin{tabular}{cc}
$\begin{array}{c}\text { Konsentrasi } \\
\text { Rumput Laut } \\
(\%)\end{array}$ & BNT \\
\hline $0 \%$ & $198,33 \pm 0,28^{\text {a }}$ \\
$5 \%$ & $147,02 \pm 0,16^{\mathrm{b}}$ \\
$10 \%$ & $132,89 \pm 0,11^{\mathrm{b}}$ \\
$15 \%$ & $112,73 \pm 0,11^{\mathrm{c}}$ \\
$20 \%$ & $96,00 \pm 0,05^{\mathrm{c}}$ \\
$25 \%$ & $70,47 \pm 0,07^{\mathrm{d}}$ \\
\hline Keterangan: 1. Setiap data merupakan hasil \\
\multicolumn{2}{c}{ rata-rata dari tiga kali ulangan } \\
dengan \pm adalah \\
2. Hundar eror \\
2. Huruf yang berbeda pada nilai \\
kadar serat menujukkan \\
perbedaan hasil yang signifikan
\end{tabular}

Tabel 4. menunjukkan bahwa semakin tinggi konsentrasi rumput laut, maka volume pengembangannya semakin rendah. Salah satu komponen pada rumput laut yang dapat mempengaruhi volume pengembagan adalah serat. Menurut Rizki, dkk., (2017), dalam penelitiannya menunjukkan bahwa, serat yang terdapat pada rumput laut dapat mempengaruhi gelatinisasi pati dikarenakan serat tidak larut air sehingga penyerapan air oleh amilum dapat berkurang. Selain serat, komponen lain yang dapat mempengaruhi volume pengembangan pada rengginang adalah protein. Protein yang terkandung pada wakame kering cukup tinggi yaitu 13,6\% (Israel, et al., 2010). Komponen protein pada rumput laut dapat menyebabkan pembentukan kompleks dengan pati, sehingga menyebabkan pengembangan menjadi berkurang pada saat digoreng. Selain dipengaruhi oleh rumput laut, volume pengembangan juga dapat dipengaruhi oleh masa pati. Masa pati berkurang akibat dari massa beras ketan yang berkurang semakin tingginya rumput laut yang ditambahkan. Menurut Astuti, dkk., (2016), granula pati dan ketersediaan air merupakan faktor yang dapat mempengaruhi volume pengembangan.

\section{Organoleptik}

Uji organoleptik dilakukan menggunakan uji hedonik atau kesukaan. Uji organoleptik dilakukan dengan 10 panelis (panelis terbatas) yang semi terlatih, dengan kriteria biasa mengkonsumsi rengginang, dan diberi penjelasan tentang kualitas rengginang dan batasan penilaian. Berikut ini hasil analisa uji Friedmain dari organoleptik rengginang rumput laut $0-25 \%$ dengan metode hedonik dalam berbagai parameter dapat dilihat pada Tabel 5.

Tabel 5. Rerata Peringkat Uji Friedman

\begin{tabular}{ccccc}
\hline Konsesntrasi & \multicolumn{4}{c}{ Peringkat } \\
\cline { 2 - 5 } $\begin{array}{c}\text { rumput laut } \\
(\%)\end{array}$ & Warna & Aroma & Rasa & Tekstur \\
\hline 0 & 3,80 & 3,00 & 3,55 & 5,25 \\
\hline
\end{tabular}




\begin{tabular}{ccccc}
\hline 5 & 2,55 & 2,50 & 3,20 & 4,05 \\
10 & 4,35 & 4,30 & 3,50 & 4,10 \\
15 & 4,30 & 5,00 & 4,45 & 4,30 \\
20 & 4,10 & 4,05 & 4,35 & 2,25 \\
25 & 1,90 & 2,15 & 1,95 & 1,05 \\
\hline
\end{tabular}

Kerterangan: $1=$ sangat tidak suka;

2= tidak suka;

$3=$ agak tidak suka;

$4=$ netral;

$5=$ agak suka;

$6=$ suka;

$7=$ sangat suka

Hasil uji friedman atribut warna menunjukkan bahwa jumlah peringkat tertinggi ditunjukkan pada perlakuan penambahan rumput laut $10 \%$ dengan nilai 4,35 (netral). Warna dalam suatu produk pangan atau bahan pangan dapat diperoleh dari pigmen yang terkandung dalam bahan itu sendiri, reaksi maillard, karamelisasi, reaksi oksidasi, serta adanya bahan pewarna baik sintetik maupun alami (Rosiani, dkk., 2015). Selain dari rumput laut, warna rengginang juga dipengaruhi oleh proses penggorengan. Beras ketan mengandung karbohidrat dan protein, sehingga adanya reaksi antara gula pereduksi dengan gugus amina dari protein yang menghasilkan melanoidin yang menyebabkan warna menjadi kecoklatan. Selain itu, adanya faktor lain seperti $\mathrm{pH}$, suhu, water activity, dan komposisi lain pada produk juga dapat mempengaruhi kecepatan dari reaksi maillard (Ibadullah, et al., 2019).

Hasil uji friedman atribut aroma menunjukkan peringkat tertinggi kesukaan panelis terhadap aroma rengginang pada perlakuan penambahan rumput laut $15 \%$ dengan nilai 5,00 (agak suka). Beberapa alasan panelis yang dituliskan pada kuisioner, pada konsesntrasi $25 \%$ aroma rumput lautnya terlalu kuat dan amis, sehingga banyak panelis yang tidak menyukainya. Menurut (Neta and Narain, 2018), aroma seperti laut, ikan, ataupun lemak biasanya terdapat pada rumput laut hijau, merah, dan coklat. Senyawa yang dapat menyebabkan aroma ikan, laut, dan lemak ini adalah amina dan pridin. Pada rumput laut wakame sendiri menurut (Lu, et al., 2018) senyawa yang dapat menimbulkan aroma laut adalah senyawa poliena yang terdapat pada wakame kering. Aroma dari rengginang ini juga terbentuk dari penambahan bawang putih. Bawang putih memilki senyawa yang dapat menimbulkan aroma yang khas pada makanan. senyawa tersebut adalah alliin (Manangka, dkk., 2017).

Hasil uji friedman atribut rasa menunjukkan peringkat tertinggi kesukaan panelis terhadap rasa rengginang pada perlakuan penambahan rumput laut $15 \%$ dengan nilai 4,45 (netral). Beberapa alasan panelis yang dituliskan pada kuisioner, pada konsesntrasi $25 \%$ rasa dari rengginangnya terlalu asin. Hal tersebut dikarenakan pada rumput laut wakame kering juga mengandung garam yang tinggi. Menurut Israel, et al., (2010), kandungan garam dari wakame kering adalah 16,8. Sehingga ketika rumput laut wakame yang ditambahkan pada rengginang semakin banyak, maka rasa asin pada rengginang tersebut akan semakin kuat. Selain dari rumput laut, rasa asin juga terjadi akibat penambahan garam pada rengginang. Menurut beberapa panelis, pada rengginang kontrol rasa asinnya tidak terlalu kuat seperti pada perlakuan yang lain, hal tersebut menyebabkan rasa gurih yang dirasakan panelis.

Hasil uji friedman atribut tekstur menunjukkan peringkat tertinggi kesukaan panelis terhadap tekstur rengginang pada perlakuan kontrol dengan nilai 5,25 (agak suka). Beberapa alasan panelis yang dituliskan pada kuisioner, konsentrasi penambahan rumput laut $5 \%$ tidak begitu keras atau teksturnya hampir sama dengan perlakuan kontrol. Sedangkan pada konsentrasi penambahan rumput laut $25 \%$, teksturnya keras. Hal tersebut dikarenakan pada adanya komponen serat pada rumput laut yang mempengaruhi tekstur rengginang. Semakin banyak serat yang ditambahkan, maka semakin banyak air yang akan diikat. Hal tersebut menyebabkan ketan tidak tergelatinisasi dengan sempurna karena kekurangan air. beras ketan yang tidak tergelatinisasi dengan sempurna, mengakibatkan produk tidak 
mengembang sehingga tektur menjadi keras (Rizki dkk., 2017). Selain itu, semakin banyak air yang diikat oleh serat, menyebabkan penguapan air semakin sedikit. Hal tersebut juga mempengaruhi pengembangan dan tekstur pada rengginang (Maureen dkk., 2016).

\section{Perlakuan Terbaik}

Perlakuan Terbaik pada rengginang rumput laut ini menggunakan metode multiple attribute (Zeleny, 1982). Perlakuan terbaik didapatkan dari parameter-parameter yang telah ditentukan pada rengginang rumput laut dengan bobot yang sama pentingnya. Pada penelitian ini, parameter yang digunakan adalah delapan parameter. Berdasarkan hasil perhitungan perlakuan terbaik yang menggunakan metode multiple attribute, didapatkan rengginang dengan penambahan rumput laut sebesar $15 \%$. Berikut ini merupakan karakteristik kimis, fisik, dan organoletik dari rengginang dengan penambahan rumput laut sebesar $15 \%$ dapat dilihat pada Tabel 6.

Tabel 6. Karakteristik Fisik, Kimia, dan Organoleptik Rengginang Rumput Laut $15 \%$

\begin{tabular}{lc}
\hline Parameter & Nilai \\
\hline Kadar Serat (\%) & $4,91 \pm 0,00$ \\
Kadar Air (\%) (bk) & $10,94 \pm 0,05$ \\
Penguapan Air (\%) & $4,38 \pm 0,00$ \\
Volume Pengembangan & $112,73 \pm 0,11$ \\
$(\%)$ & 5,50 (agak suka) \\
Warna & 6,10 (suka) \\
Aroma & 6,00 (suka) \\
Rasa & 5,70 (agak suka) \\
Tekstur
\end{tabular}

Keterangan : 1 . Nilai tersebut didapat dari rerata tiga kali ulangan dengan \pm adalah standar eror

2. Nilai organoleptik (warna, aroma, rasa, dan tekstur) didapat dari range angka 1-7 (sangat tidak suka - sangat suka)

Berdasarkan karakteristik tersebut, diketahui rerata kadar serat dari rengginang dangan perlakuan penambahan rumput laut
$15 \%$ adalah 4,91 . Hal tersebut sudah sesuai dengan PKBPOM No. 13 Tahun 2016 tentang pengawasan kalim pada label dan iklan pangan olahan, bahwa pangan olahan sumber serat harus memilki kadar serat tidak kurang dari 3 gram produk (produk padat) atau 1,5 gram per 100 kkal (produk cair). Syarat lainnya adalah harus mencantumkan infromasi nilai gizi. Selain itu, dalam pencantuman klaim juga harus memenuhi syarat asupan per takaran saji tidak lebih dari 18 gram lemak total, 4 gram lemak jenuh, $60 \mathrm{mg}$ kolesterol, dan $300 \mathrm{mg}$ natrium. Akan tetapi pada penelitian ini tidak dilakukan karena ada keterbatasan penelitian serta juga adanya kendala akibat pandemi yang sedang terjadi. Kadar air pada rengginang tersebut juga sudah sesuai SNI 01-4307-1996 Tentang Kerupuk Beras, bahwa kadar airnya maksimal $12 \%(\mathrm{~b} / \mathrm{b})$, sedangkan pada rengginang perlakuan $15 \%$ rumput laut memilki rerata kadar air sebesar $10.94 \%$ (bk).

\section{KESIMPULAN}

Penambahan rumput laut pada rengginang bepengaruh nyata $(p<0,05)$ terhadap kualitas rengginang seperti serat, kadar air, penguapan air, volume pengembangan, dan kesukaan panelis yang meliputi warna, aroma, rasa, dan tekstur. Semakin tinggi rumput laut wakame ditambahkan, maka semakin tinggi kadar serat pada rengginang. semakin tinggi rumput lat ditambahkan, maka semakin rendah kadar air, penguapan air dan volume pengembangan pada rengginang. Perlakuan terbaik didapatkan pada rengginang dengan penambahan rumput laut sebesar $15 \%$ Rengginang tersebut memilki rasa yang tidak terlalu asin, warna menarik, aroma rumput laut terasa, serta tekstur yang agak keras tetapi masih bisa diterima berdasarkan uji organoleptik yang dilakukan, kadar air 10,94\% (bk), penguapan air 4,38\%, dan volume pengembangan 112,73\%. Kandungan seratnya yang sebesar 4,57-5,19\% telah memenuhi persyaratan pangan sumber serat menurut perkbpom No. 13 tahun 2016.

\section{DAFTAR PUSTAKA}


Ardani, I., dan Yanuar., R. 2018. Studi Mutu Kerupuk Rumput Laut (Eucheuma spinosum) Kaitannya Terhadapsifat Kimiawi Dan Organoleptik. Jurnal IImu Perikanan 9 (1): 18-22

Astuti, S., Suharyono, S. S., dan Nope, F. 2016. Pengaruh Formulasi Jamur Tiram Putih (Pleurotus oestreatus) dan Tapioka Terhadap Sifat Fisik, Organoleptik, Dan Kimia Kerupuk. Jurnal Penelitian Pertanian Terapan 16 (3): 163-173

Badan Pengawas Obat dan Makanan Republik Indonesia (BPOM RI). 2016. PKBOM No. 9 Tahun 2016 Tentang Acuan Label Gizi. BPOM RI: Jakarta

Badan Pengawas Obat dan Makanan Republik Indonesia (BPOM RI). 2016. PKBPOM No. 13 Tahun 2016 Tentang Pengawasan Klaim Pada Label Dan Iklan Pangan Olahan. BPOM RI. jakarta

Badan Pusat Statistik (BPS). 2018. Pengeluaran Untuk Konsumsi Penduduk Indonesia: Berdasarkan Hasil Susenas Maret 2018. BPS RI. Jakarta

Badan Standardisasi Nasional (BSN). 2013. SNI 3160:2013 Tentang Bawang Putih (Allium sativum L.). BSN. Jakarta

Badan Standardisasi Nasional (BSN). 1996. SNI 01-4307-1996 Tentang Kerupuk Beras. BSN. Jakarta

Diana, N. E. 2016. Pengaruh Waktu Perebusan Terhadap Kandungan Proksimat, Mineral Dan Kadar Gosipol Tepung Biji Kapas. Jurnal Penelitian Pascapanen Pertanian 13 (1): 100-107

Dwiyitno. 2011. Rumput Laut Sebagai Sumber Serat. Jurnal Squalen 6 (1): 9-17

Ibadullah, W. Z. W., Atiqah, A. I., Radhiah, S., Nor, A. M., Nazamid, S., and Nur H. Z. A. 2019. Stability of Fried Fish Crackers as Influenced by Packaging Material and Storage Temperatures. Current Research in Nutrition and Food Science 7 (2): 369381

Israel, A., Einav, R., Seckbach, J (Eds). 2010. Seaweeds and Their Role in Globally
Changing Environments (Vol.15). Springer Science \& Business Media

International Food Information Council Foundation. 2018. Food and Healthy Survey. International Food Information Council Foundation. Online https://foodinsight.org/wpcontent/uploads/2018/05/2018-FHSReport-FINAL.pdf. Diakses Pada 18 November 2019.

Karjo, S. K., Suseno, T. I. P., dan Utomo, A. R. 2015. Pengaruh Proporsi Beras dan Maizena Terhadap Sifat Fisikokimia dan Organoleptik Kerupuk Puli. Jurnal Teknologi Pangan dan Gizi 14 (1): 1-9

Lu, S. J., Shohei, Y., Shiho, T., Daichi, S., and Yoshihiko, A. 2018. Characteristic Aroma Components from Dried "Wakame" Undaria pinnatifida. Journal of Oleo Science 67 (10): 1201-1207

Manangka, C. A., Linda, R., dan Mukarlina. 2017. Pemanfaatan Tumbuhan Sebagai Penyedap Rasa Alami Oleh Masyarakat Suku Dayak Kanayatn Desa Sebatih Kecamatan Sengah Temila Kabupaten Landak. Protobiont 6 (3): 158-164

Maureen S, B., Surjoseputro, S., Epriliati, I. 2016. Pengaruh Proporsi Tapikoka dan Tepung Beras Merah Terhadap Sifat Fisikokimia dan Organoleptik Kerupuk Beras Merah. Jurnal Teknologi Pangan dan Gizi 15 (1): 43-52

Musita, N. 2012. Kajian Kandungan dan Karakteristiknya Pati Resisten dari Berbagai Varietas Pisang. Jurnal Dinamika Penelitian Industri 23 (1): 5765

Neta, M. T. S. L., and Narain, N. 2018. Volatile Components in Seaweeds. Review Article: Examines in Marine Biology andOceanography Vo. 2 Issue 2: 195201

Nilasari, O. W., Susanto, W, H., dan Maligan, J. M. 2017. Pengaruh Suhu Dan Lama Pemasakan Terhadap Karakteristik Lempok Labu Kuning (Waluh). Jurnal Pangan dan Agroindustri 5 (3): 15-26 
Pereira, L. 2011. A Review of The Nutrient Composition of Selected Edible Seaweeds. Seaweed: Ecology, nutrient composition and medicinal uses, 15-47.

Pereira, L., Alan, T. C., and Ana, M. A. A Comparative Analysis of Phycocolloids Produced By Underutilized Versus Industrially Utilized Carrageenophytes (Gigartinales, Rhodophyta). Journal of Applied Phycology, 21 (5): 599-605.

Rizki, D., Sumardianto., dan Wijayanti, I. 2017. Perbandingan Penambahan Ikan Teri (Stolephorus sp.) dan Rumput Laut Caulerpa racemosa Terhadap Kadar Kalsium, Serat Kasar, Dan Kesukaan Kerupuk Ikan. Jurnal Pengolahan dan Bioteknologi Hasil Perikanan 6 (1): 46-53

Rosiani, N., Basito., dan Esti W. 2015. Kajian Karakteristik Sensoris Fisik dan Kimia Kerupuk Fortifikasi Daging Lidah Buaya (Aloe vera) Dengan Metode Pemanggangan Menggunakan Microwave. Jurnal Teknologi Hasil Pertanian 8 (2): 84-98

Yilmaz, E., and Elif, K. 2018. Funtional Crackers: Incorporation Of The Dietary Fibers Extracted From Citrus Seeds. Journal Food Science Technology 54 (10): 32083217

Zeleny, M. 1992. Multiple Criteria Decision Making. New York: McGraw-Hill 